\title{
Quality of Work Life of Muslim Women
}

\author{
Dr. Zeenat Zahoor ${ }^{1 *}$
}

\section{ABSTRACT}

Human beings are basically psychosomatic entities. They join organizations in their capacities to satisfy their economic, social and psychological needs. In any organization an employee has to adhere to the given quality of working life and play pre-formatted prescribed roles. Hence, a good quality of working life in any organization play an integral part to develop employee's working skills, positive attitudes towards their job in particular and organization as a whole, level of job satisfaction and commitment for their respective organization.

This theoretical endeavor reviews the historical perspective of quality of work life, nature and definitions of quality of work life, dimensions of quality of work life, construct of quality of work life, components of quality of work life and approaches and scopes of quality of work life. This article also explores some important aspects of Muslim female employee where quality of work life has positive effects. The article concludes with vibrant implications of quality of work life in any organization which is in thrust of development.

Keywords: Organization, Quality of work life, working conditions, Muslim women.

Work is an integral part of everyday life, as it is our livelihood or career or business. On an average we spent twelve hours daily life and it is the one third of our entire life. Human beings are basically psychosomatic entities. We join organizations in our capacities to satisfy our economic, social and psychological needs. In any organization an employee has to adhere to the given quality of working life and play pre-formatted prescribed roles. Hence, a good quality of working life of any organization play an integral part to develop employee's working skills, positive attitudes toward their job in particular and organization as a whole, level of job satisfaction and commitment for their respective organization.

An organization with high quality of work life is organizations that promotes and maintain a work environment that results in excellence in everything it does-by ensuring open communication, respect, recognition, trust, support, well-being and satisfaction of its members, both personality and professionalism

\footnotetext{
${ }^{1}$ Dept. Of Psychology, A.M.U., Aligarh

*Responding Author

(C) 2016 I Z Zahoor; licensee IJIP. This is an Open Access Research distributed under the terms of the Creative Commons Attribution License (http://creativecommons.org/licenses/by/2.0), which permits unrestricted use, distribution, and reproduction in any Medium, provided the original work is properly cited.
} 


\section{Quality of Work Life of Muslim Women}

\section{Historical Perspective of Quality of Work Life:}

The concept of quality of work life can be traced back during (1911) when a well-known scientist known as F.W. Taylor has published his book "The Principles of Scientific Management” in which he elaborated the concept of scientific management which till today form the basis for designing jobs in almost every organization across the globe. The traditional job design of scientific management focuses on division of labour, job hierarchy, close supervision and the one best way of doing work. The system of job-hierarchy has made workers totally dependent upon their superior resulting demoralization of employees' personal skills. These all consequences a demand for developing the humanized jobs which can satisfy workers higher needs, employee their higher skills and make them better citizens, spouses and parents.

This conceptual requirement of redesigning the job gave birth to the term "quality of work life" in 1960s emphasizing the human dimension of work by focusing on the quality of relationship between the worker and the working environment. Quality of work life as a discipline began in the in the United States in September (1972) when the phrase was coined by Davis at a "Democratization of Work" conference held at Columbia Universities' Arden House to discuss two movements. The first was a political movement in Western Europe called 'Industrial democracy', and the second movement was the emergence in the U.S. of a number of Social Science theorists about "Humanizing the Workplace".

Historically, the concept of quality of work life also included wages (Lawler, 1968; Seashore and Barnowe, 1972; Pierce and Danham, 1976), working hours and working conditions (West, 1969; Ganguli and Joseph, 1969; Davis, 1971; Johnson, 1979). Thus, after examining the concept and history of quality of work life we can say that quality of work life is a relatively naïve term for a bundle of old issues. It has long been of interest to philosophers, technologicians, social scientist, workers and employers. It is a broad term that can embrace every conceivable aspect of work ethics, working conditions, worker expressions of satisfaction and dissatisfaction, managerial concerns about efficiency of outputs. Quality of work life broadens considerations of social cohesions and stability.

\section{Meaning and scope of Quality of Work Life:}

The term quality of work life has different meanings to different people. Some label it as a happiness programme, others especially trade unions name it as a subtle employee incentive or just another productivity device. Quality of working life has assumed increasing interest and importance in both industrialized as well as developing countries of the world. In India, its scope seems broader than many labour legislations enacted to protect the workers. It is more than a sheer work organization movement which focuses on job security and economic growth to the employees. Thus, quality of work life refers to the level of happiness or dissatisfaction with one's career. Those who enjoy their careers are said to have a high quality of work life, while those who are unhappy or whose needs are otherwise unfilled are said to have a low quality of work life. 


\section{Quality of Work Life of Muslim Women}

To empower means to give power, authority, energy etc. A management practices of sharing information, rewards, and power with employees so that they can take initiative and solve problems and improve service and performance. Women empowerment received a wide recognition as an important subject in management circles mainly because it seen as one of the fundamental elements of managerial and organisational effectiveness that increases when power and control are shared in organization. Empowerment as delegation of power to someone has been mechanisms to increase personal and work life quality of woman in recent decades. 21st century women are now have become vital part and parcel of corporate society. Historically, India has been a male dominated society. Yet, in the past Two decades or so, social change has opened the possibility for women to attain managerial roles in corporate India. As more Indian women enter the workforce, particularly in the corporate world, this change is in dramatic contrast to the traditional Indian culture, where a woman's expected role has been to marry, raise the family and take care of the household. Since early years of the 20th century, feminism has built a body of theory and in recent decades women empowerment has been suggested as a mechanism to improve the quality of women's work as well as their personal lives. The empowerment of women is an essential precondition for the elimination of world poverty and the upholding of human rights. Today's corporate world is facing a challenge of managing its human capital which has become a critical and significant issue. The demand for talent is enormously growing across all sectors in the world. Today, women are competing at part with their male counterparts and organizations are also recognizing their talent and providing equal opportunities to them. Organizations are trying to hire the best talent, irrespective of the gender. Women have made their presence felt in every area. Moreover, they are front-runners for change and are emerging as leaders in their respective fields. Indian organization has experienced a steady increase in the number of women employees and this pattern is bound to continue in the future as well. Women recently began to join the rank of managers in large numbers. But at the top management positions are still a rare species. The changing aspirations and needs of today's workers require the union to adapt and adjust to the volatile situation. Unions can play a constructive role in the Quality of work life efforts by supporting and cooperating with the management. Presence of women in paid employment outside the home is not a new phenomenon. Dual earner households have become a salient feature of contemporary life. In recent years the participation of women in the labour market has eventually destroyed the notion that women are a peripheral part of the labour force. Women want to take up senior positions,

earn more money and be equal partners in negotiations. The Empowerment in Organisation by women and women employee empowerments significantly contributes towards improvement in quality of work life and better commitment of women employees along with achievement of prime objective of the organisations. However, its success depends upon the commitment and attitudes of the management, union, and the employees of the organisation.

\section{Need For Quality of Work Life for Working Women's:}

As from an era "Men are bread winners, women are home-makers" It was the time when husband earns and wife's were staying at home, busy with family chores. But now the time has 


\section{Quality of Work Life of Muslim Women}

changed Muslim women's are becoming professional and they are also earning. Women are allowed to work in Islam, subject to certain conditions, such as if a woman is in financial need and her employment does not cause her to neglect her important role as a mother and wife. Though the women have come out to work but still they have to cook and look after the children's. So how does she balance her work with life at home? Muslim women's in India are still struggling to establish their own identity. They have to face difficult situations because of competing demands between job and family life. But still Muslim women's are all the way to break the glass ceiling. Most Muslim women, because of familial or societal pressures, may find it difficult to continue in the same strain. The question is not whether this workplace environment is right or wrong but what can we do to make it favorable for both men and women? Where and how do we begin the process? The growing presence of professional women at workplace in India, as in other countries, is leading to a noticeable increase in dual role. Where the women try to manage work and non-work domains concurrently. The challenge in the work domain for professional Muslim women is pursuit and enhancement of dual careers, each with its demand on the commitment, time and energy of individual members. Therefore, there is an emerged need to pay attention on their quality of work life.

\section{Definitions of Quality of Work Life:}

There are no generally acceptable definitions about the term quality of work life. From the very beginning the term quality of work life has been defined differently by different psychologist, researchers and managers in their own respective ways to cover various aspects of quality of work life at large. Thus, these all can be made clearer by going through various definitions of quality of work life. They are as follows;

Taylor (1973) and Spink (1975) defined quality of work life as "the degree of excellence in the work and working conditions which contribute to overall satisfaction of the individual and enhance individual as well as organizational effectiveness". On the other hand Lippit (1977) thought quality of work life as, "the degree to which work provides an opportunity for an individual to satisfy a wide variety of personal need to survive with some security, to interact with others, to have a sense of personal usefulness, to be recognized for achievements and to have an opportunity to improve one's skills and knowledge. Here Lippit covered the whole gamut of work life which may increase organizational effectiveness.

On the basis of the available survey of literature, Nedler and Lawler (1983) came to conclude that the definition of quality of work life underwent several changes and modification, with regard to its conceptual understanding. Infact they come across six significant definitions of the term which modified through various stages developing upon the type of work environment. According Robins (1990) QWL is "a process by which an organization responds to employee needs by developing mechanisms to allow them to share fully in making the decisions that design their lives at work" 


\section{Quality of Work Life of Muslim Women}

Yousuf (1996) emphasized that quality of work life is a generic phase that covers a person's feelings about every dimension of work including economic rewards, benefits, security, working conditions, organizational and inter-personal relations and their intrinsic measuring. De (1997) believes that quality of work life is an indication of how free a society is from exploitation, injustice, inequality, oppressions and restrictions on the continuing growth of an individual.

Proceeding with the previous definitions, Lau, Wong, Chan and Law (2001) operationalzed quality of work life as the favorable working environment that supports and promotes satisfaction by providing employees with rewards, job security and career growth. Indirectly the definition indicates that an individual who is not satisfied with reward may be satisfied with the job security and to some extent would enjoy the career opportunity provided by the organization for their personal as well as professional growth.

In the recent past the definition of quality of work life given by Serey (2006) is quite conclusive and best meet the contemporary work environment. The definition is related to meaningful and satisfying work. It includes (1) an opportunity to exercise one's talents and capacities, to face challenges and situations that require independent initiative and self direction; (2) an activity thought to be worthwhile by the individuals involved; (3) an activity in which one understands the role the individual plays in the achievement of some overall goals; (4) a sense of taking pride in what one is doing and in doing it well. This issue of meaningful and satisfying work is often merged with discussions of job satisfaction, and believed to be more favorable to quality of work life. Quality of work life is defined by Lawler (2007) as "the employee perceptions of their physical and mental well-being at work”.

This review on the definitions of QWL indicates that quality of work life is a multidimensional construct, made up of a number of interrelated factors that need careful consideration to conceptualize and measure. It is associated with job satisfaction, job involvement, motivation, productivity, health, safety and well-being, job security, competence development and balance between work and non-work life. The definitions also emphasize the good feeling perceived from the interaction between the individuals and the work environment.

\section{DIMENSIONS OF QUALITY OF WORK LIFE:}

Since early 1970s psychologist and managers become interested in studying various aspects of quality of work life and a number of attempts have been made to identify various dimensions of quality of work life. Some have emphasized the improvement of work conditions leading to better quality of work life, while other feel a fair compensation and job security should be emphasized. Walton (1975) one of the major interpreters of quality of work life movement has proposed eight main conceptual categories for understanding the concept of quality of work life. These are as follows:

$>$ Adequate and fair compensation

$>$ Safe and healthy working conditions 
$>$ Development of human capacities

$>$ Growth and security

$>$ Social integration in work organization

$>$ Constitutionalization in work organization

$>$ Work and total life space

$>$ Social relevance of work life

Heizel et al. (1993) proposed four dimensions of quality of work life as ;

$>$ Growth

$>$ Mastery

$>$ Involvement

$>$ Self control

European Foundation for the Improvement of Living and Working Condition (2002) has used different set of dimensions in their quality of work life studies. The dimensions of quality of work life selected are as follows :

$>$ Health and well-being

$>$ Job security

$>$ Job satisfaction

$>$ Competency development, and

$>$ Work and non-work life balance

Quality of work life of employees has been widely studied and is it still has a greater focus on increasingly far more and more humanizing the job conditions as well as the total work environment from different angle. Thus, employee's quality of work life seems to be highly important because satisfaction of these people is a back-bone for organizational survival and development.

\section{COMPONENTS OF QUALITY OF WORK LIFE:}

A human being always functions within an environment composed of systems and subsystems, such as the physical environment, cultural environment, social environment and psychological close environment. These environmental influences imply that when criteria are considered, a wide range of factors has to be taken into account. Different categories of important job components are considered as a factor that influences the overall satisfaction with quality of work life. These are briefly discussed here as:

Demographic variables: Different authors placed emphasis on different demographic aspects. Nordenfelt (1993) commented on environmental influences. The physical environment within which the individual functions, forms the basis for his or her action On the other hand Mutran et al. (1997) researched gender differences against other variables, such as age, career phase, education and occupation in order to explore their assessment of the quality of time spent at work and their satisfaction with work. Goodman (1999) viewed power as the most valuable construct, and individuals with more seniority in the organization feel more empowered, while variables such as gender and race had no significant effect on feelings of empowerment. 
Intrinsic versus Extrinsic Job Factors: considerations in the distinction between intrinsic and extrinsic job factors, that have to do with satisfaction with quality of work life, are described by Warr (1987), Deci and Ryan (1985), Thomas and Velthouse (1990) and Snelders (1996). Extrinsic factors concern aspects of a job that form the background or context to the yask itself. It consists of activities that are externally motivated by rewards and it is carried out only because of its effects. Intrinsic factors cover aspects inherent in the conduct of the job itself. It consists of activities that are intrinsically motivating, meaning that they are rewarding by themselves.

Social factors: Social factors include social support which occurs in the form of comfort and emotional security, direct help with things like money or practical assistance and information, which can help people to solve their problems and reach decisions about their situations (Payne, 1987).

Organizational climate: Field and Abelson (1982) see job satisfaction and the climate of the organization as related. They found that the more an area of work is valued, the higher the relationship between the climate and satisfaction. They refer to experiments where different climates were created and it showed that different climates contribute to different levels of job satisfaction.

\section{APPLICATIONS OF QUALITY OF WORK LIFE AND ITS POSITIVE EFFECTS:}

QWL and career satisfaction: Career satisfaction is defined as the satisfaction individual drive from intrinsic and extrinsic aspects of their careers, including pay, advancement and developmental opportunities (Greenhaus et al. 1990). This is in contrast to job satisfaction defined as pleasurable or positive emotional state resulting from an appraisal of one's job or job experiences. On the other hand quality of work life focuses on the effects of employment on health and general well-being and ways to enhance the quality of a person's on the job experience. Quality of work life is much broader and more diverse than organizational development, in ensuring adequate and fair compensations, opportunities for personal growth and development, satisfaction of social needs at work, protection of employee rights, compatibility between work and non-work responsibilities and the social relevance of work-life (Walton, 1975; Davis et al, 1975). Thus, employees during their career will like to experience growth and development, a sense of where one is going in one's work life.

QWL, Health and well-being: Health and well-being of quality of work life refer to physical and psychological aspects of an individual in any working environment. Asakura and Fujigaki (1993) examined the direct and indirect effect of computerization on workers health and wellbeing. Their results were similar to the study of Iacovides, Fountoulakis and Kaprins (2003) that higher job demand leads to higher strain work environment; hence, it affects their health and well-being. An unstrained work environment ensures good health and psychological conditions which enable the employees to perform job and non-work related functions without inhibitions. Thus, it leads to an un-stressful work environment providing comfortable work life. 
QWL and Mental Health: A primary indicator of good or poor mental health is the level and quality of a person's effective well-being. The primary concern here is with feelings of happiness, satisfaction, high self esteem, interest in the environment and other positive emotions; or with anxiety, tension, depression, apathy, and a sense of hopelessness and generalized feelings of distress (Warr, 1987). The ultimate evaluation of the quality of life is commonly regarded by researcher as 'satisfaction with life' or happiness. Indeed, satisfaction and happiness are considered synonymous by some researchers; other suggested a relationship between these two as important dimension of quality of working life (Mukharjee, 1989).

QWL and Satisfaction/ Dissatisfaction: Satisfaction has emotional or affective components. In everyday language, satisfaction/ dissatisfaction are a feeling which determines the employee's job related behaviour. According to Seashore (1975), job satisfaction should be regarded as an attitude resulting from two concurrent, continuing evaluations in which the individual assesses his job and work environment as he perceive them; that is, whether they are likely to aid or undermined the realization of his basic values and the needs and life goals associated with it. On the other hand if the worker experiences dissatisfaction with the job or some aspect of it, he/ she will seek and find accommodation in some way. Thus, dissatisfaction is generally an unstable and transitional state. The dissatisfied job occupant will normally find ways to change his job or rationalize a change in his evaluation of it.

\section{CONCLUSION}

Quality of work life has gained a lot of importance in organizations today. The success of any organization is highly dependent on how it attracts recruits, motivates, and retains its workforce. Traditionally, Muslim females are less privileged to join the labor force, because of several social, cultural and religious norms. If they join any organization then they have to face some problems like family challenges due to which it hampers the organizational progress.

It is to be understood that the burden of managing work and family among the women professionals can result in negative mental and physiological health outcomes like, high blood pressure, headache, depression etc. Along with it acts as a barrier in their career. In this competitive environment, when the numbers of Muslim women professionals are increasing rapidly, the organization must think for providing better quality of life. They should think on the sensitive issues of making a family-friendly environment.

Ways to improve Quality of Work Life:

- The organization should go for flexible working hours.

- Childcare leave.

- Flexibility in Work location (Work from Home/Telecommuting).

- Job-sharing.

- Job Security and Safety.

- Participation in decision making.

- $\quad$ Providing prayer facilities. 


\section{Quality of Work Life of Muslim Women}

- Emergency care facilities for children's, elders.

- Support them for non-work commitments.

- Increased concern over female employees issues.

- Focus on skill development programmes for female employees.

- Building up Stress resilience through 'Well ness' programs.

- Redesigning work according to the employee's interests.

- Organization should develop Employee Assistance programs for those with family problems.

The Indian organization has to understand that societal expectations and family responsibilities do come in the way of Muslim female professionals and their career. It would help the organization to pool the talented women professionals at every level. The organization should encourage family-friendly practices. They should ensure for various work-life requirements which would help the Muslim women professionals to balance their work and family responsibilities. It's very necessary to understand that the married woman with children requires more organizational support than the unmarried and married females with no children. So it's the prime responsibility of the employers to take care while designing the human resource policies so that they can best utilize the women's potential

\section{REFERENCES}

Asakura, R., \& Y., Fujigaki, 1993. "The Impact of Computer Technology on Job Characteristics and Worker Health”. In: M.J. Smith and G., Salvendy (ed.) Human Computer Interaction: Applications and Case Studies, New York: Elsevier, pp. 982-987.

Cunningham, J.B. and T. Eberle, 1990. A guide to job enrichment and redesign. Personnel, 67: 56-61.

Deci , E. L. and Ryan, R. M. (1985) intrinsic motivation and self determination in human behavior. New York plenum press.

Devis, L.E.(1972). Paper presented at International conference, Arden House. New York, September 25-29.

Ganguli, O.N. and Joseph, J.S. (1969). A study of management morale in iron and steel industry, Ministry of Labour, New Delhi.

Johnson, J.H. (1979). Job stress in law enforcement. The role of industrial and situational variables. Dissertation Abstracts International, vol.2, pp.634A

Landy F. J. (1989) psychology of work bahaviour ( $4^{\text {th }}$ ed.) Belmant, California books/ cole publishing company.

Lau, T., Y.H., Wong, K.F., Chan, and M., Law, "Information Technology and the Work Environment-Does it Change the Way People Interact at Work". Human Systems Management, 20(3), pp. 267-280.

Lawler, E.E. (1968). Effects of hourly overpayment on productivity and work quality. Journal of personality and social psychology, vol. 10 (3), pp 306-313.

Lippit, G.L. (1977). Quality of work life; Organizational reward in action. Training and development journal, vol.32 (7), pp.4-8 


\section{Quality of Work Life of Muslim Women}

Mukharjee, R. (1989). The quality of life: Valuation in social research. New Delhi: Sage publication.

Murtan, E. J., Reitzes, D.J., Bralton, D.J. and Femandez, M.E. (1997). Self-esteem and subjective responses to work among mature workers: similarities and differences by gender. Journal of Gerontology : social science , 52 B (2), s89-s96.

Pierce, J.L. and Denham, R.B. (1976). Task Design : A literature Review. Academy of Management Review. 1976. Vol. 1. Pp 83-97.

Pyne, R.L. (1987). Organizations as psychological environment. In Warr, P. Psychology at work. London: Penguin Books.

Seashore, S.E. and Barnowe, J.J. (1972). Behind the overages : A closer look at Americans lower middle income workers. In : Industrial Relations Research Association. Proceeding of the $24^{\text {th }}$ Annual Winter Meeting. Dec.-27-28

Seashore, S.E., 1975. Defining and Measuring the Quality of Working Life. In Davis L.E. and Cherns, A.B. (Eds.), The Quality of Working Life, The Free Press, New York, NY, pp: 105-18.

Snelders, H.M.J.J. (1996). Different kinds of pay : an examination of the overjustification effect. Journal of Socio-economics, 25 (4), 517-528.

Spink, P. (1975). Some comments on quality of work life. Journal of occupational psychology, September, vol. 48 (3), pp. 179-148.

Straw, R.J. and C.C. Heckscher, 1984. QWL: New working relationships in the communication industry. Labor Studies J., 9: 261-74.

Tylor, F.W. (1911). The principles of Scientific Management. Harper and Row. New York .

Walton, R.E., 1975. Criteria for Quality of Working Life. In Davis, L.E., Cherns, A.B. and Associates (Eds.) The Quality of Working Life, The Free Press, New York, NY, 1: 91104.

Warr. P.B. (1987). Job characteristics and mental health. In Warr, P. psychology at work, London. Penguin Books.

West, L.J. (1969). Fatigue and performance variability among typist. Journal of Abnormal Psychology. Vol. 53 (1), pp 80-96.

Worrall, L. \& Cooper, C. L. (2006). The Quality of Working Life: Managers' health and well being. Executive Report, Chartered Management Institute.

Yousuf, A.S.M. (1996), evaluating the quality of work life. Management and labour studies, vol.21, pp.5-15. 